\title{
Black Torrent (Czarny potok)
}

\author{
Author: Leopold (Wincenty) Buczkowski
}

First Published: 1954

Translations: Croatian (Crna bujica, 1961); Italian (Torrente nero, 1964); English (Black Torrent, 1969); Czech (Černý potok, 1972); German (Die schwarze Flut, 1972).

About the Author: Leopold Buczkowski (1905-1989), a writer, painter, and sculptor, was born in Nakwasza near Brody in Podolia, in the former Austrian Empire. Attending an Austrian school as a child, he would demonstrate talent in a variety of artistic pursuits, including painting, graphic design, music and literature. Starting in 1914, Buczkowski lived with his family in Podkamień. After World War I, he went to a grammar school in Brody where he also worked as a stonecutter and sculptor. In 1927 he started painting, and after his military service (1928-1929), he studied Polish literature at the Jagiellonian University in Cracow. Buczkowski was later admitted as a free listener to the Academy of Fine Arts in Warsaw, where he studied painting and worked as a lithographer for a printing press. In 1934 he returned to Podkamien, where he worked as a carver and participated in the local cultural scene. Buczkowski made his literary debut in 1936 with the play Murder (Zabójstwo), which he wrote for an amateur theatre production. At the outbreak of World War II, Buczkowski was taking part in skirmishes against German troops when he was compelled to flee, hiding in the woods, and in 1944 he survived a massacre that took the lives of two of his brothers. After moving to Warsaw, he took part in the Warsaw Uprising of 1944. Later he was interested in photography, and wrote his diary (Buczkowski, 1986, p. 12). Many of his texts were destroyed by fire in Czesław Miłosz's apartment, and his remaining works would only be collected and published much later, in 2001. After the war Buczkowski settled in Cracow, where he worked primarily as a book illustrator. From 1950 until his death he lived in Konstancin, near Warsaw.

Further Important Publications: Wertepy (written 1938, published 1947, The Potholes; novel); Dorycki krużganek (1957 The Doric Cloister; novel); Młody poeta w zamku (1960, The Young Poet in the Castle; stories, illustrated by the author); Pierwsza świetność (1966, First Splendour; stories); Uroda na czasie (1970 Beauty in Time; novel); Kapiele w Lucca (1974, Spas in Lucca; a treatise in form of a novel); Wszystko jest dialogiem (1984, Everything Is Dialogue; stories); Proza żywa (1989, Living Prose; autobiography, memoirs); Żywe dialogi (1989, Living Dialogues; essays); Dziennik wojenny (2001, War Time Diary; memoirs). 


\section{Content and Interpretation}

Buczkowski is one of the most enigmatic and experimental Polish prose writers of the 20th century. His novel Black Torrent, probably finished in 1947 and not published until 1954, would become the subject of intense critical discussion due to its complex and unusual aesthetic, its elements of fantasy, and psychological realism that includes apocalyptic visions and nightmares. Buczkowski himself considered Spas in Lucca to be his opus magnum, and another novel, The Doric Cloister, is notable for the fact that he intended it to be read together with his novel Black Torrent.

Black Torrent tells the story of the Polish, Jewish, and Ukrainian partisans who fought for the Polish resistance in the former Eastern Borderlands during World War II, defending the local population with the principal aim of saving the lives of Jewish children. The novel describes an idealised binary Polish-Jewish collaboration, portraying it as a relationship of equals that transcended blood kinships and religions. The narrative provides a straightforward demonstration of the way Buczkowski's ars poetica, as a function of his enlightened humanistic upbringing, conveys his vision of human solidarity, mutual support and moral obligation under the extreme circumstances of war and genocidal terror. The protagonists, hunted by German occupying forces, fight for their survival across a bleak, hostile landscape of dark forests and waste grasslands. Buczkowski's narrative focuses on the lives of the partisans in a series of short episodic revelations, depicting events with a nightmarish immediacy, connected primarily with the destruction of the Jewish shtetl Szabasowa. Simultaneously, by virtue of his "lyrical prose", the author manages to evoke a hallucinatory atmosphere, where descriptions of brutality mingle with poetic images of singular landscapes and nature. Given to painterly as well as literary aspirations, Buczkowski approached composition in a manner reminiscent of painting with a very fine brush, especially while writing his novel "in a sanatorium", influenced by "feverish pneumonia, wartime experience, the memory of my three shot brothers [...], the Warsaw uprising and the Pruszków prison camp" (Kolińska, 1987, p. 4). The bestial conditions in which his characters suffer interminable boredom are juxtaposed to moments of terror and unbearably difficult moral decisions. While some of Buczkowski's protagonists fail tragically, others manage to preserve their human dignity even at the price of losing their lives. In Black Torrent a work of manifest narrative experimentation without any unifying authorial perspective is to be found, and no single character that would stand in for the author. The disordered plot breaks down into smaller narrative units, resembling the techniques of montage and collage.

\section{Main Topics and Problems}

Buczkowski believed, like Adorno, that after the Holocaust it was no longer possible to describe the world by means of conventional artistic methods. He therefore regarded dissonance as the only appropriate means of artistic expression for art and literature after Auschwitz. It is with this purpose that he aimed to compromise those aspects of (Western) European culture and civilisation that he saw as its faults, because 
"after all the destruction and catastrophes true writing is impossible" and only documentation seems to be adequate (Tomkowski, 2005, p. 131). Buczkowski's writing thus juxtaposes poetic fragments and rural idylls with scenes of cruelty, deploying multiple points of view to express the whole tragedy of war and genocide in an incoherent narrative. Narration is presented as if it were a kind of "archive", comprised of documents, recollections, investigations, inquiries, scenarios and accounts to form an "aggregate of reported speech” (Karpowicz, 2007, p. 47). Indeed, the writer himself regarded Black Torrent and The Doric Cloister not as novels but as works of documentation (Tomkowski, 2005 p. 131), or in any case as "studies" that the reader is compelled to dwell on as matters of fact - that the reader "should keep in mind" (p. 179). Buczkowski's departure from typical diaristic narrative conventions can furthermore be seen as an attempt to recreate the inscrutable chaos of wartime and the Holocaust by means of language. It is a language characterised not only by the special idiom of the Eastern Borderlands, but also by Buczkowski's unique use of Polish syntax and punctuation, which, together with Teodor Parnicki, Miron Białoszewski, and Andrzej Kuśniewicz, may be regarded as one of the most important representatives of Polish “experimental prose” (Buczkowski, 1986, p. 12).

\section{Cited Works}

Buczkowski, L. (1986). Proza żywa. Bydgoszcz: Pomorze. Buryła, S., Karpowicz, A., Sioma, R., eds. (2008). Zima bywa się pisarzem. O Leopoldzie Buczkowskim. Kraków: Universitas. Kolińska, K. (1987). U Leopolda Buczkowskiego. Stolica, (2), p. 4. Tomkowski, J. (2005). Wspomnienia o Leopoldzie Buczkowskim. Ossa: Dom na Wsi.

\section{Further References}

Błażejewski, T. (1991). Przemoc światła. Pisarstwo Leopolda Buczkowskiego. Łódź: Wydawnictwo UŁ. Buryła, S. (2001). Między Wertepami a Czarnym Potokiem. Zagadnienia ewolucji prozy Leopolda Buczkowskiego. Teksty Drugie, 12(2), pp. 265-273. Feldhay Brenner, R. (2016). Leopold Buczkowskis Czarny Potok: Commemoration of a Shtetl as a Humanistic Crisis. The Polish Review, 61(2), pp. 19-64. Feldhay Brenner, R. (2019). Polish Literature and the Holocaust: Eyewitness Testimonies: 1942-1947. Evanston, Illinois: Northwestern University Press, pp. 55-74. Karpowicz, A. (2007). Kolaż. Awangardowy gest kreacji. Themerson, Buczkowski, Białoszewski. Warszawa: Wydawnictwo Uniwersytetu Warszawskiego. Nycz, R. (1978). O kolażu tekstowym. Na materiale prozy Leopolda Buczkowskiego. Teksty, 4(40), pp. 9-29. Owczarek, B. (1990). Leopold Buczkowski. In: H. Olschowsky, D. Scholze, A. Lam, eds., Literatur Polens 1944 bis 1985. Berlin: Volk und Wissen, pp. 259-269. Tomkowski, J. (2005). Wspomnienia o Leopoldzie Buczkowskim. Ossa: Dom na Wsi. Trziszka, Z. (1987). Leopold Buczkowski. Warszawa: PIW. 